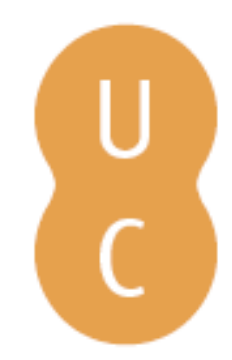

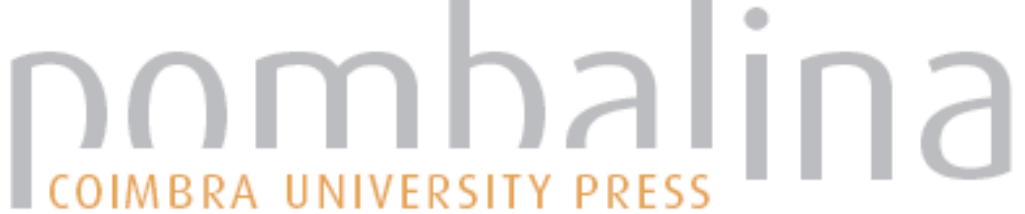

\section{Is cookery an art or a science?}
Autor(es):
Laurioux, Bruno
Publicado por: Imprensa da Universidade de Coimbra
URL persistente:
URI:http://hdl.handle.net/10316.2/45244
DOI:
DOI:https://doi.org/10.14195/978-989-26-1720-6_4

Accessed : $\quad$ 26-Apr-2023 15:34:38

A navegação consulta e descarregamento dos títulos inseridos nas Bibliotecas Digitais UC Digitalis, UC Pombalina e UC Impactum, pressupõem a aceitação plena e sem reservas dos Termos e Condições de Uso destas Bibliotecas Digitais, disponíveis em https://digitalis.uc.pt/pt-pt/termos.

Conforme exposto nos referidos Termos e Condições de Uso, o descarregamento de títulos de acesso restrito requer uma licença válida de autorização devendo o utilizador aceder ao(s) documento(s) a partir de um endereço de IP da instituição detentora da supramencionada licença.

Ao utilizador é apenas permitido o descarregamento para uso pessoal, pelo que o emprego do(s) título(s) descarregado(s) para outro fim, designadamente comercial, carece de autorização do respetivo autor ou editor da obra.

Na medida em que todas as obras da UC Digitalis se encontram protegidas pelo Código do Direito de Autor e Direitos Conexos e demais legislação aplicável, toda a cópia, parcial ou total, deste documento, nos casos em que é legalmente admitida, deverá conter ou fazer-se acompanhar por este aviso.

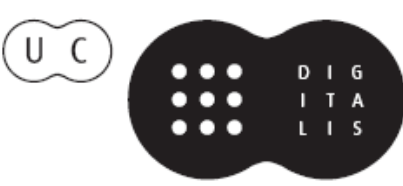


Carmen Soares

\section{Cilene da Silva Gomes Ribeiro}

\section{(coords.)}

MESAS

\section{ALIMENTAÇÃ O, SAÚDE \& CULTURA}

\section{IU LUO-BRASILEIRAS}

\section{VOLUME II}

IMPRENSA DA UNIVERSIDADE DE COIMBRA

COIMBRA UNIVERSITY PRESS

PUCPRESS 


\title{
IS COOKERY AN ART OR A SCIENCE?
}

\section{(A culinária é uma arte ou uma ciência?)}

\author{
Bruno LaUrioux \\ Université François Rabelais, Tours
}

Institut Européen d’Histoire et des Cultures de l'Alimentation

CESR - UMR 7323

BRUNO.LAURIOUX@UNIV-TOURS.FR

AвSTRACT: In the last decades, western European cuisine has undergone very spectacular changes. Among them, a "molecular cuisine" has developed a strong interest for the chemical mechanisms of the cooking process. This is not the first time in the history that cookery has tried to appear as a science: the tension between art and science, innovation and reproduction goes back as far as the Antiquity. This paper studies, from the $\mathrm{V}^{\text {th }}$ century BC onward, the cultural framework in which cookery was thought, explaining its classification as an art or a science. The first point is Greek Antiquity, with the question: "Can cookery be written, as other kinds of knowledge?" The Late Middle Ages is the second stage of our history. Scholars of this time raised the following matter: "Is cookery a part of a mechanical art or a mechanical art per se? Next point will be the Renaissance: "Did the rediscovery of Apicius' book help to define cuisine as an art in the context of the emergence of the fine arts?" Around 1730-1740, a first French "nouvelle cuisine" claimed the status of science, defining itself as a "kind of chemistry". Throughout the 19 th and 20th centuries, two opposite traditions appear: one that stresses the link between cuisine and such fine arts as architecture (Carême), another one that insists on the "scientific" part of cookery. Nowadays, everyone can notice the explosion of the area of cookery. The strict separation of art and science is recent, with the crystallization of the fine arts around the notion of creation and the figure of the author and then with the building of "modern" science. Reconciling art and science is a challenge for the present time. Maybe cookery can help to this reconciliation.

KEYWORDs: cookery, art, science, Antonin Carême, molecular cuisine.

\footnotetext{
I would like here to thank Pr. Carmen Soares who invited me to present a first draft of this paper at the " $3^{\text {rd }}$ Portuguese and Brazilian DIAITA Conference on Food History and Cultures" untitled Dos Prazeres da Mesa aos Cuidados do Corpo (Coimbra, 19-21 October 2015) and the members of this Conference who helped me to improve my arguments. Thanks also to Dr. Robin Nadeau who invited me to present a second draft of this paper at the workshop Cooking Knowledge: An Intellectual History of Food and Cuisine (Budapest, Central European University - Institute for Advanced Study, 8 April 2016). And last but not least, I am very grateful to my colleague, Pr. Véronique Pauly, who kindly agreed to translate this paper into English.
} 
RESUMO: Nas últimas décadas, a culinária européia ocidental sofreu mudanças espetaculares. Entre elas, uma "cozinha molecular" desenvolveu um forte interesse pelos mecanismos químicos do processo de cozimento. Esta não é a primeira vez que a gastronomia tentou aparecer como uma ciência: a tensão entre arte e ciência, inovação e reprodução remonta até a antiguidade. Este artigo estuda a partir do século V a.C., o quadro cultural em que a culinária foi pensada, explicando sua classificação como arte ou ciência. O primeiro ponto é a antiguidade grega, com a pergunta: "A culinária pode ser escrita como outros tipos de conhecimento?" O final da Idade Média é o segundo estágio da nossa história. Os estudiosos de esta época levantaram o seguinte assunto: "A culinária é parte de uma arte mecânica ou uma arte mecânica per se?” O próximo ponto será o renascimento: "Foi a redescoberta do livro de Apicius que ajudou a definir a gastronomia como uma arte no contexto do surgimento das belas artes?" Por volta de 1730-1740, uma primeira "novela de cozinha" francesa reivindicou o status de ciência, definindo-se como um "tipo de química". Ao longo dos séculos XIX e XX, aparecem duas tradições opostas: uma que busca o vínculo entre a gastronomia e as belas artes como a arquitetura (Careme), e outra que insiste na parte "científica" da gastronomia. Hoje em dia, todos podem notar a explosão da área de culinária. A separação rigorosa da arte da ciência é recente, com a cristalização das belas artes em torno da noção de criação e da figura do autor, e depois com a construção da ciência "moderna". Conciliar arte e ciência é um desafio para o presente. Talvez a culinária possa ajudar a essa reconciliação.

Palavras-Chave: culinária, arte, ciência, Antonin Carême, cozinha molecular.

In the last decades, western European cuisine has undergone very spectacular and rather conflicting changes: an opening to the exotic tastes of World Cuisine coexists with the celebration of the cultural food heritage of different countries or regions; a taste and care for organic or healthy foods have not prevented a "molecular cuisine" from developing, with a strong interest for the chemical mechanisms of the cooking process.

This is not the first time in the history that cookery has tried to appear as a science. It was already the case in France in the beginning of the last century, when the famous Auguste Escoffier asserted, in the preface to the second edition of his Guide culinaire: "without ceasing to be an art, cookery will become scientific and will have to submit its formulas, still too often empirical, to a method and a precision that will not leave anything to chance"2.

\footnotetext{
"En un mot, la cuisine, sans cesser d'être un art, deviendra scientifique et devra soumettre ses formules, empiriques trop souvent encore, à une méthode et à une précision qui ne laisseront rien au hasard" (Escoffier 1912: IX). This sentence lacks in the foreword of the first edition, in which we read: "Pour combattre les désastreux effets de la suractivité moderne sur les centres nerveux, elle deviendra même plus scientifique et plus précise” (Escoffier 1903: VII).
} 
To some extent, Escoffier's proclamation was a response to the one that Carême published one century earlier when he declared that, among the five fine arts, architecture had pastry as main branch ${ }^{3}$. Interestingly, Carême is quoted by Prosper Montagné, Escoffier's contemporary and Escoffier himself is quoted by Thierry Marx, the French "pope" of molecular cuisine ${ }^{4}$. It seems that nothing has changed during the last two centuries.

In fact, the tension between art and science, innovation and reproduction goes back as far as the Antiquity. We can study, from the Vth century BC onward, the cultural framework in which cookery was thought, explaining its classification as an art or a science. For this study, I chose six points. Each one allows us to ask a fundamental question whose answer requires using a particular kind of text.

The first point is Greek Antiquity. The question is: Can cookery be written, as other kinds of knowledge? The main documents are here the first books of culinary recipes and also some philosophical texts. The context is, indeed, the delimitation of two areas of knowledge: episteme (that will become scientia in Latin) and tékhne (that will be translated as ars).

The End of the Middle Ages is the second stage of our history. Scholars of this time, who wrote books on classification of the sciences, raised the following matter: Is cookery a part of a "mechanical art" (like hunting or agriculture) or a "mechanical art" per se?

Next point will be the Renaissance: Did the rediscovery of Apicius' book help to define cuisine as an art in the context of the emergence of the fine arts? Humanistic works, titles and prefaces to cookbooks can be used here.

Around 1730-1740, a first French "nouvelle cuisine" claimed the status of science, defining itself as a "kind of chemistry". To study this point, we can use again prefaces to cookbooks, in the particular context of the "Quarrel of the Ancients and the Moderns".

Throughout the $\mathrm{XIX}^{\text {th }}$ and $\mathrm{XX}^{\text {th }}$ centuries, it seems that two opposite traditions appear. The one initiated by the great chef Antonin Carême, who stresses the link between cuisine and such fine arts as architecture; another tradition (as in Brillat-Savarin's Physiologie du goutt) insists on the "scientific" part of cookery.

Nowadays, everyone can notice, as I wrote in the beginning of this paper, the explosion of the area of cookery - and even if the French pope of "molecular cuisine", chef Thierry Marx, pretends that this "innovating cookery

\footnotetext{
"The fine arts are five in number: painting, sculpture, poetry, music, and architecture whose main branch is pastry" ("Les beaux-arts sont au nombre de cinq, à savoir: la peinture, la sculpture, la poésie, la musique, l'architecture, laquelle a pour branche principale la pâtisserie"). This sentence is quoted by Montagné 1938: 289.

Marx, Haumont 2012: 4.
} 
is by no means in break-up with the tradition" and that the "new knowledge and tools will leave a greater part to creativity, through innovation"s.

\section{i. Greek Antiquity: cookery as a Written KnOWledge}

For Antiquity, I am heavily dependent on my colleagues' works, particularly the synthesis by Andrew Dalby, and the papers published in one very interesting volume coordinated by Carmen Soares and Paula Barata Dias ${ }^{6}$. One important paper of Robin Nadeau has recently dealt with the issue of cookery books in Greek and Roman Cultures ${ }^{7}$.

We know that cookery books existed in Greece from the $I^{\text {th }}$ (maybe $\mathrm{V}^{\text {th }}$ ) century $\mathrm{BC}$ onward, but only by fragments, which can be found in papyri (like those preserved in Heidelberg ${ }^{8}$ ), in lexicographic repertories (for instance a recipe for thrion in Pollux ${ }^{9}$ ), and above all in a fascinating encyclopedia of food habits in the Ancient Time, the Deipnosophists, written by Athenaeus of Naucratis in the third century ${ }^{10}$. Sometimes it is only the title of the recipe book which has been preserved, but we are not even sure that this title was the good one. The fact is well known for a poem by Archestratus of Gela, mixing recipes with lists of food specialties, which is called by Athenaeus either Hedypatheia ("Life of Pleasure") or Gastronomia ("Rules for the stomach") ${ }^{11}$.

As Carmen Soares has noticed ${ }^{12}$, the literary genre of cookery books seems to have been denoted by the expression Opsartytika Biblia, that is to say "Books for preparation of opson", and cookery itself by opsopoiia, "making of opson" - opson, that Andrew Dalby translates as "relish", denotes itself food which is not bread (we can maybe find an equivalent in the medieval Latin word companaticum, "what is served with bread"). Thus, the first fact to remember is that cookery was a written knowledge in Ancient Greece.

We can add that some cookery books were written even before Ancient Greece, as early as Mesopotomia of the second Millenary before Christ: the recipes now preserved in Yale Babylonian Collection, written on cuneiform tablets, were published and translated by late Jean Bottéro ${ }^{13}$.

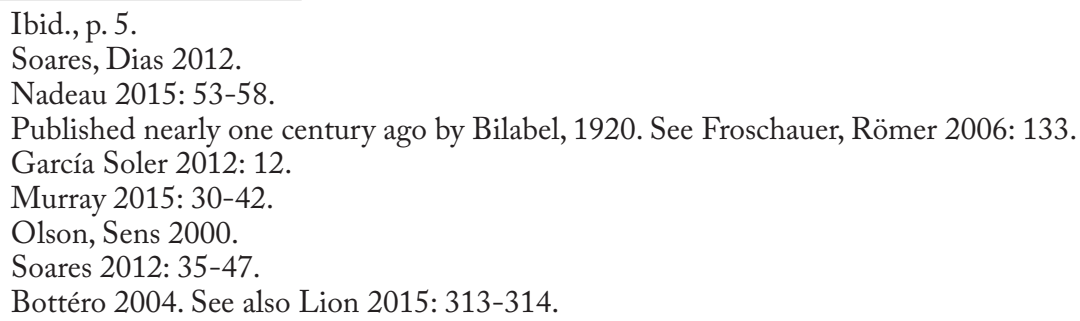


Second remark, the cookery production from Antiquity didn't completely disappeared during the High Middle Ages. Three manuscripts of Apicius'work were copied between VIII ${ }^{\text {th }}$ and IX $^{\text {th }}$ centuries. The codices in which they were included are very different in their writing, layout, and contents, suggesting quite different uses ${ }^{14}$. The most interesting case is a collection, now dismembered between Switzerland and United States, which gathers Apicius' and Hippocrates' texts together ${ }^{15}$. Unlike my previous hypothesis ${ }^{16}$, Apicus' cookbook was considered as useful for Food, and not only for knowledge of Latin ${ }^{17}$.

Even if cookery was a written knowledge in Ancient Greece, was it considered as an art? To answer this question, let us turn to philosophical texts studied by Carmen Soares ${ }^{18}$. In one chapter of his Memorable, Xenophon shows Socrates discussing with friends about the meaning of some nouns: they agree that the name of opsophagos (eater of opson) can be applied to the one who eats meat, without bread and without physical necessity. In the same way, Socrates, according to Xenophon, condemns people who eat several dishes together because it doesn't fit to the "art" of cookery. The term used by Xenophon here is tékhne, that is to say a knowledge which has not the status of science (episteme).

Even this status of "art" is denied to cookery by Plato, in a long passage of one of his most important dialogues, the Gorgias. In fact, Plato chooses cookery as an example to demonstrate that rhetoric is not an art but just a practice (empeiriai) which doesn't aim to do good but only to please - unlike justice (for rhetoric) and medicine (for cookery). But his thought seems to have evolved in this matter, since in The Politician he ranks cookery (that he called here mageiriké tékhne) among the seventh species of science for the body (the one dedicated to food), alongside medicine but also agriculture, hunting and gymnastics.

If Aristotle, in his Politics, takes up this idea of a food science, more precisely of a science of cookery (episteme opsopoiike), he clearly defines it as a science for slaves. These terminological and ideological choices will be very important for the history of cookery.

\footnotetext{
14 Laurioux 2016: 467-492.

15 New York, Academy of Medicine, ms. 1 et Cologny, Fondation Bodmer, ms. 84.

Laurioux 1994: 17-38.

As shown in Dr. Asfora's works: Asfora 2016: 493-513 and Asfora 2014.

Soares 2012.
} 


\section{Middle Ages: Cookery as a mechanical art}

From the XII ${ }^{\text {th }}$ century - and the didactic treatise of Hugh of Saint Victor -, Cookery is clearly seen as a "mechanical art" (or a part of it) ${ }^{19}$.

But what is a mechanical art? ${ }^{20}$ The idea is not new: as early as the VIIth century, Isidore of Seville used the word mechanica to denote the kind of knowledge linked to crafts $^{21}$. What the Greeks called Banausikai were "denigrated" and "treated with contempt in the cities", as wrote Xenophon in his Economics's . Mediaeval Christendom inherited this contempt for manual work, and the crafts were sometimes referred to disparaging phrases as artes minores, artes vulgares, illiberales, serviles, adulterinae or sordidae. The main point was the opposition to the liberal arts, which were considered as the privilege of free people.

The first scholar to speak of mechanicae artes was the Carolingian philosopher (and skillful in Greek) Johannes Scotus Eriugena in his commentary on a very important allegorical text from the Late Antiquity orator Martianus Capella, entitled On the Marriage of Philology and Mercury. As Martianus Capella counted seven liberal arts (which would structure mediaeval education until the XII ${ }^{\text {th }}$ century at least), John Scot claimed that "after Mercury will have given seven liberal arts, then the Virgin will give seven mechanical arts". Unfortunately he quoted only one of these mechanical arts - architecture -, the other ones being referred as "et caetera" 23 .

The aim of Hugh of Saint Victor is precisely to give a complete list of the seven mechanical arts. The master of a famous monastic school, he wrote a Didascalicon to organize the readings of his pupils. As a consequence, the Didascalicon also tries to classify the whole knowledge. Interestingly, the mechanical arts (what Hugh called in fact "mechanical sciences") have an important place in this encyclopedia. And among them, hunting (venatio), about which Hugh writes: "to this discipline belongs the preparation of all food, seasoning and drink" 24 . The foods that he quotes as an instance are very different from actual food of Hugh's time: in fact, the list is taken from Isidore of Seville's encyclopedia (Etymologies), which tries to make an inventory of all the words and the realities of the Ancient World. Most of

19 I develop this point in « La cuisine est-elle un art ou une science? Retour sur un vieux problème », to be published in Mélanges Danielle Jacquart.

20 On the question of mechanical arts, see Sternagel 1966; Whitney 1990; Ovitt Jr. 1987: 107-136.

${ }_{21}$ De differentiis rerum, PL 83, col. 94.

22 Xénophon, Économique, IV, 2, ed. \& trad. fr. Chantraine 1971: 45-46.

23 Iohannis Scoti Annotationes ad Marcianum in Lutz, 1939: 74, 1. 20-21.

24 Didascalicon II, 25: Hugonis de Sancto Victore Didascalicon De Studio Legendi, in Buttimer 1939: 42-43. 
these food have nothing to do with hunting and Hugh has to explain that if food science gets its name from one of its part, "it is because, in Antiquity, people live mostly on the products of hunting". But he admitted that food could also belong, by some point of view, to medicine or agriculture: "the preparation of food belongs to bakery, the preparation of meat to cookery and the virtues of seasoning to medicine".

That's why, after Hugh of Saint Victor, many mediaeval scholars tried to give a more important place to food, which, from then on, was considered as a mechanical art per se: victuaria for Radulphus Ardens at the end of the XIIth century, who regards hunting as a part of food and not the contrary; to this victuaria belong also agriculture, fishing, bakery and cuisine (coquinaria) ${ }^{25}$. Around 1250, Robert Kilwardby suggests naming this science cibativa or nutritiva, as an echo to the aristotlelician "science of making" (factiva or poïetike) ${ }^{26}$.

I think that this process, which individualizes and promotes food, and even cookery, is not unconnected with another process, which allows cookery to be written ${ }^{27}$. Thanks to a recent discovery, we know that recipes adapted to mediaeval cookery were written as early as the XII ${ }^{\text {th }}$ century, just when Hugh of Saint Victor wrote the Didascalicon ${ }^{28}$. Therefore, the cooks, who imagined these recipes and composed, around 1300, new cookery books, were still considered as simple craftsmen. Their title of master referred to the fact that they managed a staff of workers and apprentices, like in any ordinary workshop.

The prefatory remarks that we find in some cookbooks of the $\mathrm{XV}^{\text {th }}$ and $\mathrm{XVI}^{\text {th }} \mathrm{c}$. can be still understood in this context: cooks are supposed to know "the science of art" (sic) of cookery as writes Maître Chiquart, chef of the duke of Savoy around $1420^{29}$.

\section{Renaissance: Cuisine as one of the "fine arts"}

As early as the beginning of the XIV ${ }^{\text {th }}$ century, we find a small cookery book which is written in Danish but whose Latin title is Libellus de arte coquinaria. Its text seems to be connected with German tradition ${ }^{30}$. Therefore, in this early period, titles are not stable, for the cookbooks as well as for the whole textual production. So it is not before the middle of the $\mathrm{XV}^{\text {th }}$ century that we find a second book whose title is related to culinary art. This is the

\footnotetext{
25 Grabmann 1909: 254.

26 Robert Kilwardby, De ortu scientiarum, XL, 377, in Judy 1976: 140; Whitney 1990: 122.

27 Laurioux 2005a.

28 Cambridge. Sidney Sussex College $\Delta .3 .6$, pt. 4, fol. 39r-v. To be published by Giles Casper \& Faith Wallis.

29 Ed. Scully 1985: $127 \& 130$.

30 Grewe, Hieatt 2001: 27-28.
} 
famous collection of recipes gathered by Maestro Martino, who served as cook successively for the duke of Milano, the cardinal and patriarch of Aquileia Ludovico Trevisan, the pope Paul II and the condottiere Giangiacomo Trivulzio ${ }^{31}$. Two manuscripts give it the title of Libro de Arte coquinaria ${ }^{32}$. It is well known that the humanist Platina borrowed the recipes of the De honesta voluptate from Martino's collection ${ }^{33}$. Interestingly, the description of the good cook that Platina develops in his book - giving Martino "The man from New Como" as an example - insists on his "art". Here is the translation by the great specialist of Apicius and Platina, Mary Ella Milham ${ }^{34}$.

On the Cook. One should have a trained cook with skill (arte) and long experience, patient with his work and wanting especially to be praised for it. He should lack all filth and dirt and know in a suitable way the force and nature of meats, fish and vegetables so that he may understand what ought to be roasted, boiled, or fried. He should be alert enough to discern by taste what is too salty or too flat; if possible, he should be completely like the man from New Como, the prince of cooks of our age, from whom I have learned the art of cooking food (obsoniorum conficiendorum rationem). He should not be gluttonous or greedy, as was the Frenchman Marisius, so as not to appropriate and devour what his master is supposed to eat.

It is not by chance if this very laudatory portrait of the good cook occurs in a humanist's work. In the $\mathrm{XV}^{\text {th }}$ century, Humanistic circles welcomed the rediscovery of Apicius' cookery collection that they renamed De re coquinaria ${ }^{35}$. Among connoisseurs of Apicius' work there were of course some physicians ${ }^{36}$ and some members of the Academia Romana created by Pomponio Leto, a good friend of Platina whose group was dedicated to the celebration of Antiquity. But also Angelo Poliziano, who collated the two Carolingian Apicius' manuscripts, now preserved in Vaticano and New York. In the same time, Poliziano wrote a short treatise on classification of the sciences, The Panepistemon ("all the sciences"), in which coquinaria is ranked among mechanical artes as prestigious as architecture, graphic art and theater ${ }^{37}$.

31 Laurioux 2005b: 141-154.

32 Ms. Washington, Library of Congress, ms. 153: ed. Faccioli, 1966: t. 1, p. 119; see also Maestro Martino 2005. Another manuscript that bears this title was formerly owned by Firmin-Didot and Pichon, but is no more located: see Laurioux 2005c: 13-17.

33 Laurioux 2006: 523-524.

34 Platina, On Right Pleasure and Good Health, ed. \& trad. Milham 1998: 118-119.

35 Laurioux 1994.

36 As recently shown by Wanessa Asfora Nadler, "Apício como opus medicinale na Itália do século XV: estudo de caso dos manuscritos mediceo e ficiniano", in Dos Prazeres da Mesa aos Cuidados do Corpo.

37 Coquinariae capita Graeca referam, qualia ponit Apitius. Ea sunt epimeles, artoptus, cepurica, 
From the humanist point of view, Cookery is thus a recognized knowledge, because based on one ancient authority: Apicius ${ }^{38}$, who is to cookery what Vitruvius is to architecture and Terentius to theater.

As a consequence, cookery recipe became a literary genre. Originally written by cooks, probably for the use of butlers who could thus supervise the work of the kitchen, the cookbooks began to be spread among larger categories of medieval society, through manuscripts and, from the 1480's, printed copies $^{39}$. The culinary writing inspired authors who inserted recipes in their literary works, like, in the first half of the XVI ${ }^{\text {th }}$ century, The Baldus of Teofilo Folengo, known also as Merlin Cocaio (Merlin the Cook), which contains twenty versified doctrinae cosinandi (recipes for cooking), supposed to be practiced in Jupiter's kitchen but in fact borrowed from contemporary cookbooks. Folengo's intention was probably not to exalt cooks' work: the use of macaronic language, blending Latin with various dialects from Italy, is deliberately droll and parodic ${ }^{40}$.

Using colors and shaping dishes with different consistencies, the cook could have been easily classed as an artist, painter or sculptor, whose status began to evolve during the XVI ${ }^{\text {th }}$ century ${ }^{41}$. Actually, the plates of Scappi's Opera (published in 1570 and the first one to be richly illustrated) can be seen as both professional (which equipment that needs to be used for cooking) and aesthetic: the kitchen is shown as the theater in which the master cook and his whole brigade work ${ }^{42}$.

However, the title Art of Cookery or Culinary Art seems to have been rarely given to a cookbook from the XVI ${ }^{\text {th }}$ to the XVIII ${ }^{\text {th }}$ centuries, except in Spain ${ }^{43}$ or in Portugal ${ }^{44}$. Even in France, whose Cuisine invades the whole

pandecter, osprion, trophetes, polyteles, tetrapus, thalassa, halieus. Hanc Plato adulatricem medicinae appellat (Operum Angeli Politiani tertius tomus: ejusdem praelectiones, orationes, epigrammata complectens..., Lyon, Seb. Gryphium, 1546, p. 44). On Panepistemon, see Mandosio 1996: 135-164; Mandosio 1997: 331-390.

38 Hugh of Saint-Victor seems to have not a direct knowledge of Apicius' book that he quotes through Isidore of Seville.

39 Laurioux 1997a; Laurioux 1997b.

40 Faccioli 1966: t. I, p. 240-251.

41 Csergo 2012:13-36. This scholar uses the very interesting concept of "artification du culinaire".

42 Opera di M. Bartolomeo Scappi, cuoco secreto di papa Pio V, Venezia: Michele Tramezzino, 1570. See the reprint Bologna, 1981. The Venice edition of 1598 printed by Alessandro Vecchi, which includes Il Trinciante by Vincenzo Cervio and Il Maestro di Casa by Cesare Pandini, bears a different title: Dell'arte del cuoco, del Trinciante, e Mastro di Casa and, from 1610, simply Dell' Arte del cucinare; Schino, Luccichenti 2007: 70.

43 As soon as 1520: Libre de doctrina per a ben servir de tallar y del art de coch by Master Robert (ed. Leimgruber 1982), translated in Castilian in 1525. In 1609 was published a new edition of Diego Granado Maldonado's cookbook untitled Libro del arte de cozina and, in 1611 Francesco Martínez Montiño published the Arte de cocina, pastelería, etc.

44 Domingos Rodrigues, Arte de Cozinha, Lisboa, 1680. See in England too, the Accom- 
Europe from the middle of the XVII ${ }^{\text {th }}$ century, the most successful French cookbook is simply entitled Le Cuisinier Français (The French Cook) ${ }^{45}$ and the only art to be referred to in the titles of French cookery books of the XVII ${ }^{\text {th }}$ century is the Art "de bien traiter", that is to say to "treat well" (the guests) ${ }^{46}$.

\section{XVIII ${ }^{\mathrm{Th}}$ CENTURY: "NOUVELle CUISINE" as A SCIENCE}

The first French Modern cookbook referring to an "Art of cookery" in its title is the Suite des Dons de Comus ou L'Art de la cuisine réduit en pratique, published by François Marin in 1742. In an apparent Paradox, this book was supposed to be a continuation of another collection, Les Dons de Comus, whose preface had been a manifesto for culinary science ${ }^{47}$.

Although its authorship is under discussion ${ }^{48}$, the preface to Les Dons de Comus clearly distinguishes a Modern Cuisine from an Ancient Cuisine ${ }^{49}$. Simpler and more learned than the Ancient One, this Modern Cuisine is defined as a "kind of chemistry"

The science of the cook consists today in decomposing, in rendering easy of digestion, in quintessencing the foods, in extracting from them light and nourishing juices, and in so mixing them together, that no one flavor shall predominate, and that everything can be felt; finally in giving different foods this unity that the painters give to colors and in making them so homogenous that their different flavors produce a subtle and racy taste, and $[\ldots]$ an harmony of all the flavors gathered together ${ }^{51}$.

plisht Cook, Or The Art E Mystery of Cookery, "wherein the whole ART is revealed in a more easie and perfect Method than hath been publisht in any language", by Robert May, London, 1660. Even the old Viandier, can refer, from the XVI ${ }^{\text {th }}$ century, to " l'art \& science de appareiller viande ", a formula which is very close of the Chiquart's one (Taillevent Grand Cuysinier du Roy de France, Paris, Guillaume Nyverd, 1500/1519).

45 La Varenne, Le Cuisinier françois, Paris: Pierre David, 1651, reprint with a foreword by Hyman, Hyman 2001.

46 L.S.R. (1674), L'Art de bien traiter, Jean du Puys, Paris.

47 Les Dons de Comus ou les délices de la table (1739), Prault, Paris, 1739.

48 Livres en bouche 2001: 205, n. 198.

49 Hyman and Hyman 1989: 73a-74c.

50 Les Dons de Comus..., "Avertissement", p. xix-xx: "On distingue aujourd'hui chez les gens du métier \& chez les personnes qui se piquent d'avoir une bonne table, la Cuisine ancienne \& la Cuisine moderne. La Cuisine ancienne est celle que les François ont mise en vogue par toute l'Europe, \& qu'on suivoit generalement il n'y a pas encore vingt ans. La Cuisine moderne établie sur les fondemens de l'ancienne, avec moins d'embarras, moins d'appareil, \&avec autant de variété, est plus simple, plus propre, \& peut-être encore plus sçavante. L'ancienne Cuisine étoit fort compliquée, \& d'un détail extraordinaire. La Cuisine moderne est une espece de Chymie.”

51 Ibid., p. xx-xxi: "La science du Cuisinier consiste aujourd'hui à décomposer, à faire digerer $\&$ à quintessencier des viandes, à tirer des sucs nourrissans \& legers, à les mêler \& les 
The reference to painting clearly shows that this "science" can be compared to an "art" 52 . Important also is the fact that cookery was compared to chemistry, a science whose separation from alchemy really began with the "Enlightenment" ${ }_{53}$. But the most important was the qualification of Marin's Cuisine as "Modern". Fifty years before, an author only known by his initials LSR, already criticized the book written by La Varenne as not up-to-date ${ }^{54}$. But opposing Modern to Ancient Cuisine was a clear echo to the "Quarrel of the Ancients and the Moderns" which had begun in the 1630's and had been revived in the 1710 's $\mathrm{s}^{55}$. Mostly literary, this debate was also about "sciences and arts" and Cookery was a topic of the Quarrel: Charles Perrault, in the last volume of his Parallel between Ancients and Moderns (1697), asserts that "we have cooks with more taste than the Ancients had" ${ }_{56}$.

\section{XIX ${ }^{\mathrm{TH}}$ AND $\mathrm{XX}^{\mathrm{TH}}$ CENTURIES: TWO TRADITIONS}

The $\mathrm{XIX}^{\text {th }}$ and $\mathrm{XX}^{\text {th }}$ centuries combined the two traditions that we have described. Antonin Carême (1784-1833) ${ }^{57}$ was the main representative of an aesthetical cuisine ${ }^{58}$ which can be described as architectural ${ }^{59}$. When he was a young apprentice, he made sketches of historical monuments or garden pavilions which strongly inspired his cuisine ${ }^{60}$. This tradition of "artistic cuisine" was transmitted through Carême's disciples, such as Urbain Dubois (1818-1901) whose "pieces montées" were very spectacular. Another Carême’s

confondre ensemble, de façon que rien ne domine \& que tout se fasse sentir; enfin à leur donner cette union que les Peintres donnent aux couleurs, $\&$ à les rendre si homogenes, que de leurs differentes saveurs il ne resulte qu'un goût fin $\&$ piquant, $\&$ si je l'ose dire, une harmonie de tous les goûts réunis ensemble."

52 Quellier 2007: 221-224.

53 See the important and recent book by Kahn 2016.

54 “... on ne verra point icy les absurdités, \& les dégoutantes leçons que le Sieur de Varenne ose donner, \& soutenir...” (L.S.R., L'Art de bien traiter, here quoted from the edition of Lyon: Claude Bachelu, 1693, p. 4-5). See Livres en bouche 2001: 63.

55 See Fumaroli 2001.

56 Parallèle des Anciens et des Modernes ou il est traitté de l'astronomie, de la Geographie, de la Navigation, de la Guerre, de la Philosophie, de la Musique, de la Medecine, Ẽ c. Cinquième et dernier dialogue par M. Perrault, t. IV, Paris: Jean-Baptiste Coignard, 1697, p. 281-282: "[Le chevalier] Si l'art de la Cuisine qui à mon sens en vaut bien un autre, doit entrer en lice, je suis persuadé que nous avons des Cuisiniers d'un goust tout autrement delicieux que n'en avoient les Anciens. [L'abbé] Il n’en faut pas douter. Les Anciens ont eu soin de nous laisser par écrit plusieurs de leurs plus excellens ragousts; ceux qui en ont voulu essayer les ont trouvez détestables."

57 For a summary of Carême's works, career and cuisine, see Ferguson 2004: 49-82.

58 When Carême speaks of "artistic cooking", it is about the "service à la française" (L'Art de la cuisine française au XIX' siècle, quoted by Hyman 2001: 80.

59 Bonnet 1977: 23-43.

60 Hayden 1996: 39-44. 
disciple, Jules Gouffé (1807-1877), is a representative of the second trend in the French Cuisine: the scientific approach. According to him, cooking requires watching constantly the clock and using constantly the balance ${ }^{61}$.

In the $\mathrm{XIX}^{\text {th }}$ century, the most famous name linked with the scientific approach is Brillat-Savarin (1755-1826), allegedly - but erroneously - creator of "gastronomy". In a very quoted part of his Physiologie du goût, he distinguished three kinds of cuisine. Only the first one is dedicated to preparation of food, the second one can be called "chemistry" and the third one "pharmacy" During the $\mathrm{XX}^{\text {th }}$ century, Édouard de Pomiane (1875-1964) was a typical representative of the scientific approach. Besides "gastronomie", which is considered as an art that strikes the senses, he distinguished "gastrotechnie" which is a real science ${ }^{63}$. This "gastrotechnie" was the melting pot of our "molecular cuisine", a science that studied "the good or bad modifications that occur in food during the cooking process" ${ }^{64}$.

Even the French "New Cuisine" of the 1970's is a mix of artistic and scientific approaches. Among the famous "Ten Commandments" of this New Cuisine, there is indeed "you won't be systematically modernist" but also "you will try to find what the new techniques can give you" and "you will be inventive" ${ }^{65}$.

${ }^{61}$ "Je n'ai pas rédigé une seule de mes indications élémentaires sans avoir constamment l'horloge sous les yeux et la balance à la main. Je m’empresse d'ajouter qu'on n'est pas obligé d'avoir constamment recours, dans la pratique, à ces moyens de vérification absolue, du moment où l'on est devenu un ouvrier habile et consommé. Mais lorsqu'il s'agit de formuler pour les personnes qui n'ont pas encore de connaissances acquises, je déclare qu'on ne saurait procéder d'une façon trop rigoureuse." (Jules Gouffé (1867), Le Livre de Cuisine: comprenant la cuisine de ménage et la grande cuisine avec 25 planches imprimées en chromolithographie et 161 gravures sur bois dessinées d'après nature par E. Ronjat, Hachette, Paris). See Rambourg 2005: 175-187.

${ }_{62}$ "Quand on voit les choses d'en haut, on peut compter jusqu'à trois espèces de cuisine: La première, qui s'occupe de la préparation des aliments, a conservé le nom primitif; La seconde s'occupe à les analyser et à en vérifier les éléments: on est convenu de l'appeler chimie; Et la troisième, qu'on peut appeler cuisine de réparation, est plus connue sous le nom de pharmacie." Brillat-Savarin, La Physiologie du goût ou Méditations de Gastronomie Transcendante, t. 2, Paris: A. Sautelet, 1826, Méditation XXVII, "Histoire philosophique de la cuisine”, p. 133-134.

63 Pomiane 1950: 7-12 and 168-170. Studied at the Institut Scientifique d'Hygiène Alimentaire, this science "ramène l'étude de toutes les techniques culinaires à celle d'un nombre restreint de phénomènes physiques et chimiques: dialyse, osmose, coagulation et peptonisation des albumines, caramélisation des sucres, dextrinisation et saccharification des amidons, émulsion des graisses, genèse chimico-physique des émulsions et des gels..." (Pomiane 1950: 170).

64 "Il existe cependant, toute une science nouvelle étudiant les modifications, heureuses ou malheureuses, survenues dans les aliments au cours de leur cuisson. Cette science s'appelle la gastrotechnie" (Pomiane 1940).

65 Gault, Millau 1973: “...4. Tu ne seras pas systématiquement moderniste. 5. Tu rechercheras cependant ce que t'apportent les nouvelles techniques. [...] 10. Tu seras inventif.” 


\section{Conclusion}

Nowadays, the tension still exists between innovation and repetition. Even Nathan Myhrvold, who wrote Modernist Cuisine ${ }^{66}$ and pretends to prepare a potted goose without any fat, claims that cookery is also an $\operatorname{art}^{67}$. For ordinary people, interviewed during a sociological survey, cookery is still an art, even a visual art, which can be compared to painting ${ }^{68}$.

The meaning of "art" and "science" has deeply evolved from Antiquity to the XVIII ${ }^{\text {th }}$ century: if based only on translation, the comparison is dangerous. As long as ars designated a particular skill and knowledge based more on practice than on theory, it was not so far from a "science". The strict separation of art and science is recent, with the crystallization of the fine arts around the notion of creation and the figure of the author and then with the building of "modern" science. Reconciling art and science is a challenge for the present time. Maybe cookery can help to this reconciliation.

\section{BibLIOGRAPHY}

Asfora, W. (2014), Apício. História da incorporação de um livro de cozinha na Alta Idade Média, Alameda Editorial, São Paulo.

Asfora, W. (2016), "Apicius in the Early Medieval Manuscripts: Medieval or Roman Cookery Book?", Atti delle Settimane della Fondazione Centro Italiano di Studi sull'Alto Medioevo 63: 493-517.

Bilabel, F. (1920), OYAPTYTIKA und Verwandtes, Heidelberg, (Sitzungsberichte der Heidelberger Akademie der Wissenschaften. Philosophisch-historische Klasse, 23).

Bonnet, J.-C. (1977), "Carême ou les derniers feux de la cuisine décorative”, Romantisme 17-18: 23-43.

66 Myhrvold 2011.

67 "Quand on ose avancer que la cuisine, c'est un peu plus que de la science, Nathan Myhrvold rétorque: 'La cuisine, c'est de l'art! Mais l'art a aussi besoin de la science. Prenez un architecte: si vous lui expliquez les dernières recherches sur la résistance de certains matériaux, par exemple, il aura plus de liberté de création. Les cuisiniers ont aussi besoin de technique pour inventer!"' (interview en ligne: <http://www.lexpress.fr/styles/saveurs/modernist-cuisine-le-livre-ultime_1051937.html>).

68 "A la fin de l'entretien, la question suivante était posée: la cuisine est-elle un art au même titre que la peinture? Sur trente personnes interrogées, seules sept ont exprimé l'avis que la cuisine n'est pas un art visuel, car sa finalité est d'être bonne à manger, même si on cherche à la rendre plus appétissante en la rendant plus agréable à voir; les autres ont toutes affirmé que la cuisine était un art et que l'esthétique visuelle jouait un rôle aussi important que le goût. 'C'est l'art de tous les jours', Marie-Paule, 69 ans, niveau BTS, retraitée, $2000 €$ de revenu mensuel; 'La cuisine est un art même s'il existe de mauvais plats comme il existe de mauvais tableaux, pourtant ce n'est pas pour ça qu'on pense que la peinture n'est pas un art', Fanelie, 22 ans, niveau BTS, chômage, 700 € par mois." (Csergo 2012: 22). 
Bottéro, J. (2004), The Oldest Cuisine in the World: Cooking in Mesopotamia, University of Chicago Press, Chicago.

Buttimer, C. H. (ed.) (1939), Didascalicon II, 25: Hugonis de Sancto Victore Didascalicon de studio legendi, The Catholic University Press, Washington.

Csergo,J. (2012), “L'art culinaire ou l'insaisissable beauté d'un art qui se dérobe. Quelques jalons (XVIIIe-XXIe siècle)”, Sociétés E̊ Représentations 34.2: 13-36.

Escoffier, A. (1903), Le guide culinaire. Aide-mémoire de cuisine pratique, Bibliothèque Professionnelle, Paris.

Escoffier, A. (1912, 3. a ed.), "Introduction à la deuxième édition", in Le Guide culinaire. Aide-mémoire de cuisine pratique, Bibliothèque Professionnelle, Paris.

Faccioli, E. (ed.) (1966), Arte della Cucina. Libri di ricette, testi sopra lo scalco, il trinciante $e$ i vini dal XIV al XIX secolo, Il Polifilo, Milan.

Ferguson, P. P. (2004), "Inventing French Cuisine”, in Accounting for Taste. The Triumph of French Cuisine, University of Chicago Press, Chicago-London, 49-82.

Froschauer, H., Römer, C. (eds.) (2006), Mit den Griechen zu Tisch in Ägypten, PhoibosVlg, Wien.

Fumaroli, M. (2001), La Querelle des Anciens et des Modernes, with an essay by Marc Fumaroli, Gallimard, Paris.

García Soler, M. J. (2012), "La presencia de la gastronomía en la literatura griega”, in C. Soares, P. B. Dias (ed.), Contributos para a história da alimentação na antiguidade, Imprensa da Universidade de Coimbra, Coimbra, 11-24.

Gault, H., Millau, C. (1973), "Vive la nouvelle cuisine française”, Nouveau Guide Gault et Millau 54.

Grabmann, M. (1909), Die Geschichte der scholastischen Methode, Herder, Freiburg im Breisgau, t. I.

Grewe, R., Hieatt, C. B. (eds.) (2001), Libellus de arte coquinaria: an Early Northern Cookery Book, Mrts, Tempe (Az).

Hayden, P. (1996), “The Fabriques of Antonin Carême”, Garden History 24.1: 39-44.

Hyman, M., Hyman, P. (ed.) (1989), "La Première Nouvelle Cuisine”, in L'Honnête Volupté. Art culinaire, Art majeur, Éditions Michel de Maule, Paris, 73-74.

Hyman, M., Hyman, P. (ed.) (2001), La Varenne, Le Cuisinier françois, Pierre David, Paris 1651, Manucius, Pau.

Hyman, P. (2001), "Culina Mutata: Carême and l'ancienne cuisine”, in L. R. Schehr, A. S. Weiss (eds.), French Food. On the table, on the Page and in French Culture, Routledge, New York-London, 71-82.

Judy, A. G. (ed.) (1976), Robert Kilwardby, De ortu scientiarum, British Academy, London.

Kahn, D. (2016), Le fixe et le volatil. Chimie et alchimie, de Paracelse à Lavoisier, CNRS Éditions, Paris.

Laurioux, B. (1994) “Cuisiner à l'antique: Apicius au Moyen Âge”, Médiévales 26: 17-38.

Laurioux, B. (1997a), Les Livres de cuisine médiévaux, Brepols, Turnhout. 
Laurioux, B. (1997b), Le Règne de Taillevent. Livres et pratiques culinaires à la fin du Moyen Age, Publications de la Sorbonne, Paris.

Laurioux, B. (2005a), Une histoire culinaire du Moyen Âge, Champion, Paris.

Laurioux, B. (2005b), "Le prince des cuisiniers et le cuisinier des princes: nouveaux documents sur Maestro Martino, cocus secretus du pape", Médiévales 49:141-154.

Laurioux, B. (2005c), “Maestro Martino' Cookery Book and Its Manuscripts”, in Maestro Martino "Libro de arte coquinaria", Rome, ca. 1465. The Katherine Golden Bitting Collection, Library of Congress, CD-Rom, Octavo, p. 13-17.

Laurioux, B. (2006), Gastronomie, humanisme et société à Rome au milieu du XVE siècle: autour $d u$ De honesta voluptate de Platina, Sismel Edizioni del Galluzzo, Florence.

Laurioux, B. (2016), "Cuisine, médecine et diététique: traditions, rencontres, distorsions entre le $\mathrm{V}^{\mathrm{e}}$ et le $\mathrm{XII}{ }^{\mathrm{e}}$ siècle", in L'alimentazione nell'alto medioevo. Pratiche, simboli, ideologie, Centro italiano di studi sull'alto medioevo, Spoleto, 467-492.

Leimgruber, V. (ed.) (1982), Mestre Robert, Libre del coch. Tractat de cuina medieval, Curial Ediciones Catalanes, Barcelone.

Lion, B. (2015), “Mesopotamia”, in J. Wilkins, R. Nadeau (eds.), A Companion to Food in the Ancient World, Wiley, Chichester, 309-318.

Livres en bouche (2001), Livres en bouche. Cing siècles d'art culinaire français, du quatorzième au dix-huitième siècle, BnF-Hermann, Paris.

Lutz, C. E. (ed.) (1939), Iohannis Scotti Annotationes in Marcianum, Cambridge (Mass.), Cambridge.

Maestro Martino (2005), Maestro Martino "Libro de arte coquinaria", Rome, ca. 1465. The Katherine Golden Bitting Collection, CD-Rom, Library of Congress, Octavo.

Mandosio,J.-M.(1996), "Filosofia, arti e scienze: l'enciclopedismo di Angelo Poliziano”, in L. Secchi Tarugi (ed.), Poliziano nel suo tempo, Franco Cesati Editore, Florence.

Mandosio, J. (1997), "Les sources antiques de la classification des sciences et des arts à la Renaissance”, in D. Jacquart (ed.), Les Voies de la science grecque. Études sur la transmission des textes de l'Antiquité au dix-neuvième siècle, Droz, Genève, 331-390.

Marx, T., Haumont, R. (2012), Le répertoire de la cuisine innovante, Flammarion, Paris.

Milham, M. E. (ed.) (1998), Platina, On Right Pleasure and Good Health, Medieval \& Renaissance Texts \& Studies, Tempe (Az).

Montagné, P. (1938), Larousse Gastronomique, Larousse, Paris.

Murray, O. (2015), “Athenaeus the Encyclopedist”, in J. Wilkins, R. Nadeau (eds.), A Companion to Food in the Ancient World, Wiley, Chichester, p. 30-42.

Myhrvold, N. (2011), Modernist Cuisine: The Art and Science of Cooking, The Cooking Lab, Bellevue.

Nadeau, R. (2015), "Cookery Books", in J. Wilkins, R. Nadeau (eds.), A Companion to Food in the Ancient World, Wiley, Chichester, 53-58.

Olson, D., Sens, A. (2000), Archestratos of Gela. Greek Culture and Cuisine in the Fourth Century BCE, Oxford University Press, Oxford.

Ovitt Jr., G. (1987), The Restoration of Perfection: Labor and Technology in Medieval Culture, Rutgers University Press, New Brunswick, 107-136. 
Pomiane, E. (1940), Cuisine et restrictions, Corrêa, Paris.

Pomiane, E. (1950), La Physique de la cuisine et son art. 700 plats très simples, Albin Michel, Paris.

Quellier, F. (2007), La Table des Français. Une histoire culturelle (XV-début XIXe siècle), Presses Universitaires de Rennes, Rennes.

Rambourg, P. (2005), "L'art culinaire, ou la cuisine artistique", in De la cuisine à la gastronomie. Histoire de la table française, Audibert, Paris, 175-187.

Schino, J., Luccichenti, F. (2007), Il cuoco segreto dei papi. Bartolomeo Scappi e la Confraternita dei cuochi e dei pasticcieri, Gangemi, Roma.

Scully, T. (1985), “Du fait de cuisine par Maistre Chiquart, 1420”, Vallesia 40: 103-231.

Soares, C. (2012), “Arte Culinária em Xenofonte, Platão e Aristóteles”, in C. Soares, P. Dias (eds.), Contributos para a história da alimentação na Antiguidade, Imprensa da Universidade de Coimbra, Coimbra, 5-47.

Soares, C., Dias, P. B. (eds.) (2012), Contributos para a história da alimentação na Antiguidade, Imprensa da Universidade de Coimbra, Coimbra.

Sternagel, P.(1966), Die Artes Mechanicae im Mittelalter. Begriffs-und Bedeutungsgeschichte bis zum Ende des 13, Jahrhunderts, Kallmünz.

Whitney, E. (1990), Paradise Restored: the Mechanical Arts from Antiquity through the Thirteenth Century, The American Philosophical Society, Philadelphie.

Xénophon (1971), Économique, IV, 2, ed. \& trad. fr. Pierre Chantraine, CUF, Paris, 45-46. 